\title{
Chronology and Palaeoenvironment of Levantine Prehistoric Sites as Seen from Sediment Studies
}

\author{
William R. Farrand ${ }^{a}$
}

\begin{abstract}
Analysis of sediments from the sites of et-Tabun, Jebel Qafza, and Sefunim in Israel, of Ksar 'Aqil in Lebanon, and of Yabrud Rockshelter I and Jerf 'Ajla in Syria leads to a reconstruction of the environments of deposition, periods of weathering and erosion, and relations to changing sea level during the times of occupation of these sites by prehistoric man. The overlapping sequences span the interval from part or all of the last interglaciation through the time of the last glaciation into historic time. Aeolians and from the last interglacial littoral zone and aeolian silt from more distant deserts dominate the site sediments until the early part of the last glaciation (especially at Tabun), whereas colluvial slope deposits, alluvium (Ksar'Aqil), and angular rockfall debris are characteristic of the mid-last glaciation sediments in most sites, commonly with an admixture of reworked terra rossa soil sediment. These latter sediments seem to reflect a period or periods of greater available moisture or surface run-off. Prominent unconformities mark many sites at times coincident with the final middle palaeolithic (mousterian) occupations or in the interval between middle palaeolithic and upper palaeolithic occupations. It is not clear, in the absence of firm radiometric dates, whether these hiatuses should be correlated from site-to-site or whether they are site-specific. Freeze/thaw phenomena appear not to have played a significant role, if any at all, in the origin of sediments in coastal Levantine sites, although the middle palaeolithic of the Syrian Desert (Yabrud, Jerf 'Ajla) is contained in typical cryoclastic rubble. Finally, the reconstructed sedimentary environments are compared with the still-too-sparse palynological record for the Near East. Parallels of more humid and less humid climatic intervals throughout the past 60,000 to 70,000 years in both of these records reinforce the growing impression of a regionally fluctuating climate in the castcrn Mediterranean region during the time of the last glaciation.
\end{abstract}

Keywords: NEAR EAST, ISRAEL, LEBANON, SYRIA, ET-TABUN, QAFZA, KSAR 'AQIL, MIDDLE PALAEOLITHIC, UPPER PALAEOLITHIC, SEDIMENTOLOGY, CHRONOLOGY, PALAEOENVIRONMENT.

\section{Introduction}

In 1969 I made a first attempt to establish a chronology of Levantine sites based purely on geological information (Farrand, 1972). Although the principles of such a correlation were sound, modern geological studies of those sites were immature or incomplete at that time. Only three seasons of the recent excavations at Tabun had taken place, only a few

${ }^{a}$ Department of Geology and Mineralogy, The University of Michigan, Ann Arbor, Michigan 48109, U.S.A. 
samples had been collected at Qafza, and I had not yet visited the site Ksar 'Aqil. Sedimentological studies of these sites have progressed considerably since that time and, although none of them is yet complete, they now provide a firmer basis for advancing ideas about late Quaternary chronology and palaeoenvironment of the Levant.

Three sites will be discussed in some detail in this paper and several others described briefly; their locations are shown in Figure 1. The first of these is the Tabun Cave on the coast of Israel, where the University of Michigan-University of Arizona excavations were conducted in 1967-1971 under the direction of A. J. Jelinek. Preliminary results on the geology, palynology and vertebrate fossils have been published (Jelinek et al., 1973). The second site is the cave of Jebel Qafza, on the outskiris of Nazareth in central Galilee, about $35 \mathrm{~km}$ due east (inland) from Tabun. Descriptions of the human remains (Vandermeersch, 1966, 1969, 1977; Tiller \& Vandermeersch, 1976), of the upper palaeolithic industries (Ronen \& Vandermeersch, 1972), and of the vertebrate fossils (Haas, 1972; Bouchud, 1974) have appeared, but the sediments are reported on here for the first time. The third site to be considered in detail is the rockshelter of Ksar 'Aqil, only $10 \mathrm{~km}$ northeast of Beirut in Lebanon. Several notes on the archacology have appeared so far based on the excavations begun in 1969 by Tixier (1974), but as in the case of Qafza, this is the first published report on the sedimentology of this site. However, the earlier work of Wright (1962) is still quite valuable inasmuch as it describes the general geological setting of Ksar 'Ayil in a valley that has been drastically changed in the past 15 years or so by major quarry activity.

By way of general comment before proceeding to the description and analysis of the individual sites, I would like to reiterate the rationale behind this kind of study. The immediate goal is to provide a chronological and environmental framework within

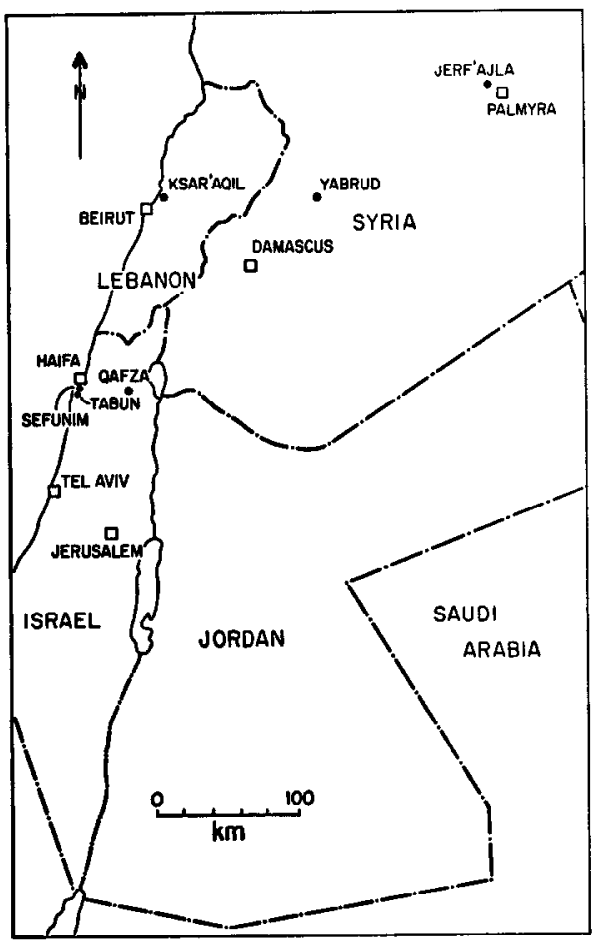

Figure 1. Index map of prehistoric sites discussed in text. 
which the cultures and industries found in the individual sites can be evaluated. This is approached strictly from a geological point of view, using the specific techniques of sedimentology, stratigraphy, geomorphology and palaeontology, as well as absolute dating methods. On the other hand, the artifacts will not, and cannot be used as a means of establishing time relations between sites; such a procedure can only result in circular reasoning since onc of our main goals is the dating of the artifacts. I have commented on this procedure in greater detail previously (Farrand, 1972).

\section{Stratigraphic Nomenclature}

Admittedly this is not the place to enter into a major discussion of the principles of stratigraphic practice, but it is necessary that each of us respect these principles if we are going to attempt a realistic reconstruction of the geologic past. Much confusion has arisen, for example, through the failure to distinguish between rock, time-stratigraphic, time and climatic units, on one hand, and the casual extension of nomenclature defined in one geographic area to some other area, even to another continent. The latter usage implies an equivalence that is well beyond proof and that is deleterious to the establishment of a meaningful correlation chart involving the two areas. The classic and most widespread example of the latter kind of misuse is the application of the Alpine glacial chronology, which is not really so clear even in the Alps (Richmond, 1970; Kukla, 1977; Brunnacker, 1975), to non-glacial stratigraphy as far away as Israel and Lebanon, or even in southern Africa and India. Local terminology must be established and clearly defined-first for rock units (formations) and then for local time-stratigraphic units based on those rock units and keyed to absolute dates wherever possible. Then, and only then, can distant correlations be hypothesized. It is clearly incorrect to speak of the Würm Glaciation in Israel, or anywhere else, except in the Alps.

In the absence of an established local time-stratigraphic framework for the Near East the term "last glaciation" will be used provisionally herein, specifically in the sense of "the time equivalent to the last major continental glaciation of the northern continents," that is, equivalent grosso modo to the Weichselian or Wisconsinan stages of northern Europe and North America, respectively. A "glaciation" strictly speaking is a geologicclimate unit, according to the American Code of Stratigraphic Nomenclature (American Commission on Stratigraphic Nomenclature, 1970) and may be time-parallel or timetransgressive. An "interglaciation" is the time between glaciations in which evidence of a glacial climate is lacking. Through the intermediary of eustatic marine shorelines glaciations and interglaciations can be traced theoretically all round the world. Even though the onset of glaciation may not have been absolutely synchronous in North America and in northwestern Europe or elsewhere, the world ocean integrates the effects of this storage of water in ice sheets in such a way that relatively abrupt changes in sea level become better indicators of the onset and demise of global continental glaciation than the evidence left by the ice sheets themselves. Eustatic sea levels close to or higher than present sea level can thus be assigned to an interglaciation, while sea levels distinctly lower than that of today belong to a glaciation. Therefore, the "last glaciation" can also be viewed as the time that elapsed between the last period of high sea levels prior to those of the Holocene epoch and the beginning of the Holocene. Concordant absolute dating around the world has now established limits of c. 75,000 and 10,000 years B.P. for the "last glaciation" so defined.

I would like to stress further the value of marine stratigraphy, especially in coastal areas such as the Levant, as a means of establishing a chronological scale. When proper attention is paid to the tectonic factor, so that simple altitudinal correlation of shorelines is recognised as unsatisfactory, comparison of detailed coastal sedimentary sequences around the shores of a single ocean or sea would be a primary tool for long-distance 
correlation. For our purposes we have the good works of Sanlaville $(1969,1973)$ for the Levant and of Butzer (1975) for the western Mediterranean, who have set up two local, but very similar, chronologies to which studies in other local areas can be related (e.g. Farrand \& Ronen, 1974). Moreover, radiometric dating has shown that these local Mediterranean chronologies correlate well with other late Quaternary marine sequences around the world, thus providing a real opportunity for the evaluation of time relations between climatic episodes and human cultural change in the Near East with those in northwestern Europe or elsewhere. It is in this context that my reference time scale (below: scc "Conclusions") has becn designed; it reflects the local marine stratigraphy of the Levant and the very reasonable correlation of that stratigraphy with marine stages of the western Mediterranean, especially as defined by Bonifay (1975). The absolute age of the early part of the northern European glaciation has recently been confirmed by refined radiometric dating (Grootes, 1978).

\section{Methods of Study}

The sediments on which these studies are based were sampled in the presence of the responsible archaeologist at each site, generally during the course of recent excavation. The usual procedure consisted of sampling one or more columns of sediments vertically from the uppermost beds down to the lowest beds exposed by the excavators. One sample would be collected from each layer that appeared to differ in any way (colour, grain size, compaction, stoniness, etc.) from the immediately overlying or underlying layers. If an apparently homogeneous layer was unusually thick, i.e. more than about $25 \mathrm{~cm}$, several samples would be collected from it in order not to miss any subtle variations. Each sample spans about $10-15 \mathrm{~cm}$ of the stratigraphic thickness, which means in some cases that a given sediment sample may incorporate more than one archaeological level if the latter are particularly thin. (Archaeological content was not a consideration in sediment sampling, although the archaeological stratigraphy and the geological stratigraphy were firmly linked in all cases.) Large samples, up to $20-25 \mathrm{~kg}$, were collected from coarsegrained strata in order to assure a statistically sufficient sample of the coarsest material studied. Stones and rock fragments larger than $128 \mathrm{~mm}(-7 \mathrm{phi})$ were noted in the field, but not collected.

In the laboratory the sediments were submitted to the following analyses: grain-size distribution by manual measurement of the stone fraction, sieving of the sand fraction and hydrometer analyses of the silt-and-clay fraction. The roundness and porosity of the stone fraction were measured, and the presence of any concretionary coatings was noted. For the fine fraction the calcium carbonate and organic matter contents were routinely measured, as well as the heavy mineral and clay mineral components. In some cases more detailed chemical analyses were made, especially for phosphates and iron. The specific results of these analyses are given in the reports already published or in preparation for each of the sites in question, and a more detailed review of these procedures can be found in Farrand (1975).

\section{General}

\section{Site Descriptions}

It is not the purpose of this paper to describe each site in great detail; in fact, analysis is not yet complete for some of the sites discussed below. Only the highlights of recent sedimentological work will be presented, and the reader will be referred to pertinent previous publications for background information on the sites. A generalized stratigraphic column is given in Figure 7 for each site discussed, and a similar column showing the placement of prehistoric industries within the stratigraphy is found in Figure 8. 


\section{Et-Tabun, Mount Carmel, Israel}

New excavations begun in 1967 have greatly supplemented the basic study of the Carmel caves by Garrod \& Bate (1937). In addition to a general preliminary statement (Jelinek et al., 1973) on the new excavation, Jelinek $(1975,1977)$ has discussed some of the implications of the artifact assemblage in light of current ideas on middle palaeolithic industries of the Levant. However, much of the information, geological and palaeontological as well as archaeological, gleaned from the recent work remains to be published. Detailed sedimentological study by Goldberg (1973) forms the basis for many of the conclusions presented here.

The cave of et-Tabun is situated along a former wave-cut cliff at the foot of the Mount Carmel block, where it faces westward across the coastal plain toward the Mediterranean. The Mediterranean shoreline is now about $2.5 \mathrm{~km}$ west of the Carmel front at this point, but at the time of the beginning of the sedimentary record in Tabun the shoreline was right at the foot of the Carmel cliff. Traces of this old shoreline have been found at many points along the Carmel front by Michelson (1968) who mapped it as the "Tyrrhenian I" shore. One outcrop of these coastal deposits is situated just across the wadi from Tabun, at $39 \mathrm{~m}$ above present sea level-or about $6 \mathrm{~m}$ below the entrance sill of Tabun. Although Michelson attributed this shoreline to the interglacial preceding the last one, it seems morc likely to us, for scvcral rcasons, that it should in fact be included in the group of shorelines dating from the last interglacial. Our reasons include (a) the logical relation of windblown sand in Tabun $G$ and perhaps in Tabun $F$ that must have been derived from such a source, (b) the necessity for a high groundwater table in the cave during Tabun $G$ time in order to support those sediments that subsequently collapsed, and (c) the observation that the deposits in Tabun $G$ through $D$ appear to represent one essentially continuous sedimentary sequence without any evidence of a major unconformity or weathering interval that should be present if Tabun G sediments were related to an interglacial some $90-100,000$ years older than that of Tabun $F$ to $D$. The argument that the relatively high altitude of this shoreline $(39-45 \mathrm{~m})$ militates against its being included in the last interglacial does not appear to have any significant weight. Other Quaternary shorelines occur up to 100 and $120 \mathrm{~m}$ above sea level in this part of the Mount Carmel block (Michelson, 1968), so that ample evidence of Quaternary uplift of the Carmel exists.

The correlation of the $+39 \mathrm{~m}$ shoreline with Tabun $\mathrm{G}$ deposits is the starting point in the interpretation of the Tabun sedimentary sequence. The succeeding deposits in the cave can also be related to the shifting Mediterranean shoreline during late Quaternary time (Figure $2 \mathrm{a} \& \mathrm{~b}$ ).

The Tabun deposits were subdivided into beds $A$ to $G$ by Garrod, and these designations are still useful for general discussions of the stratigraphy. However, it was quickly clcar to us that the carlicr cxcavators did not respect the natural stratigraphy of the site in some areas, and elsewhere their subdivisions were based strictly on differences in artifact assemblages, not on geological criteria. As detailed elsewhere (Jelinek et al., 1973), we have delineated some 60 natural beds from the top of Garrod's Tabun C down to the upper part of Tabun F.

As mentioned above, the sequence from Tabun $G$ to the top of Tabun D appears to represent one continuous period of deposition with only minor interruptions or disruptions. Tabun $\mathrm{G}, \mathrm{F}$ and the lower half of $\mathrm{E}$ consist dominantly of fine-grained, wellsorted sand, essentially identical with modern dune sand and with fossil dunes behind the present beach (Figure 3). These sands have been disturbed by two episodes of slumping into a subterranean cavity that lies below the outer chamber of Tabun. Slumping first occurred after the deposition of bed G, and again near the end of the deposition of bed F, although the latter disturbance is not yet entirely understood. In both instances the 

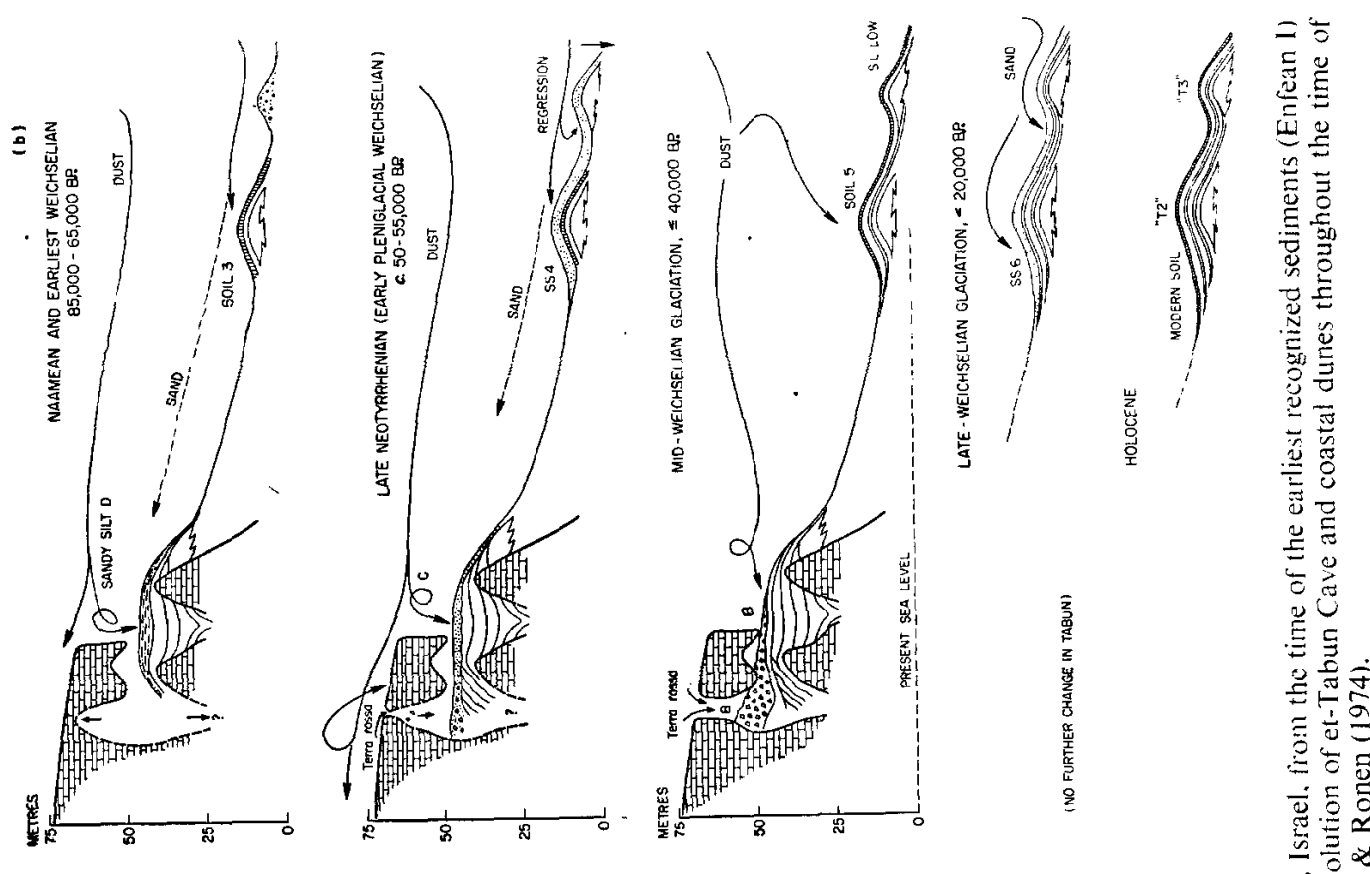

㐘

至要
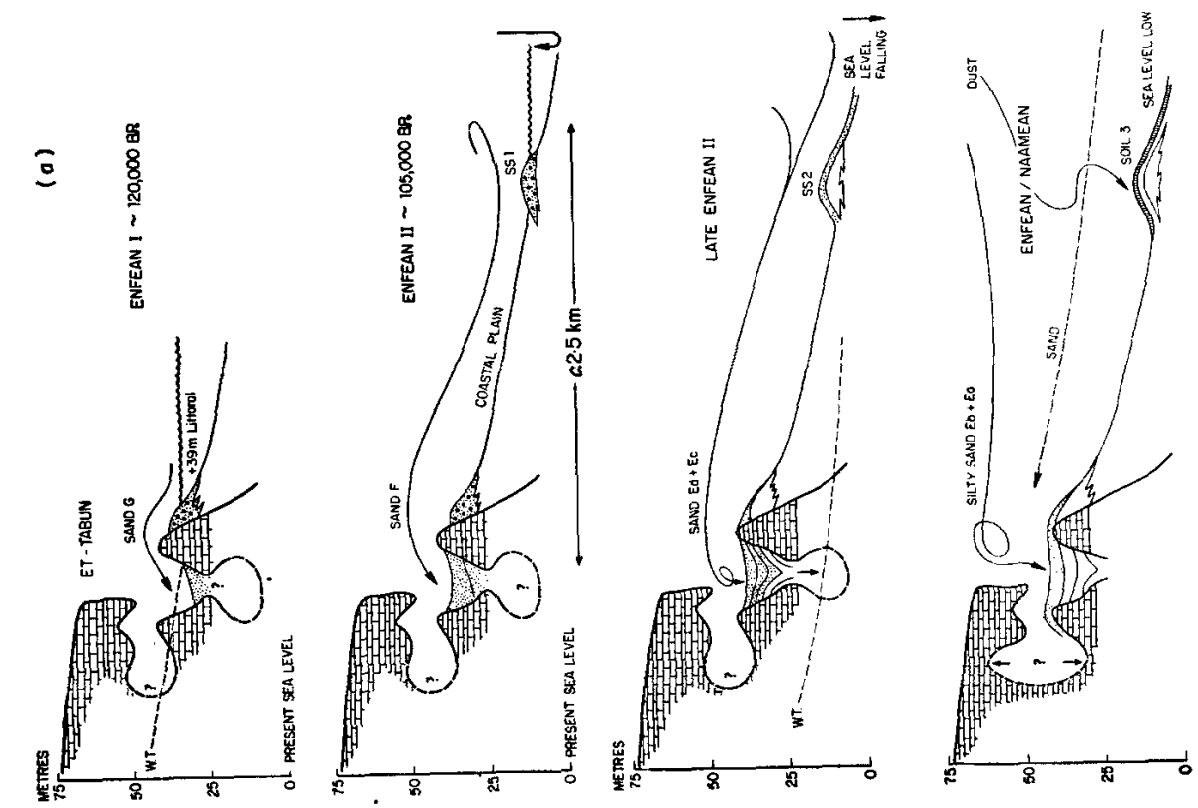

焉总㤩 可品

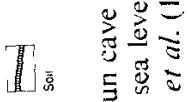

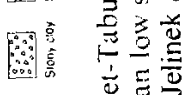

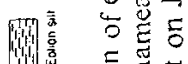

国動

习习习

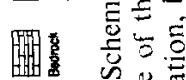

త.

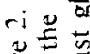

揱言焉 
slumping appears to have been caused by a lowering of the groundwater table, which removed the hydrostatic pressure that previously had supported these beds.

The alternation between the accumulation of windblown sands and the slumping related to groundwater withdrawal can be interpreted within the framework of sea level fluctuations registered along the Mediterranean coast. The $+39 \mathrm{~m}$ beach has already been mentioned; other fluctuations are seen in the several long ridges of cemented dune sand (kurkar ridges) that parallel the modern coastline. These ridges include several generations of dune sand superimposed on a core of littoral marine sand, and the dune sands are separated by strong reddish brown hamra palaeosols that indicate periods of

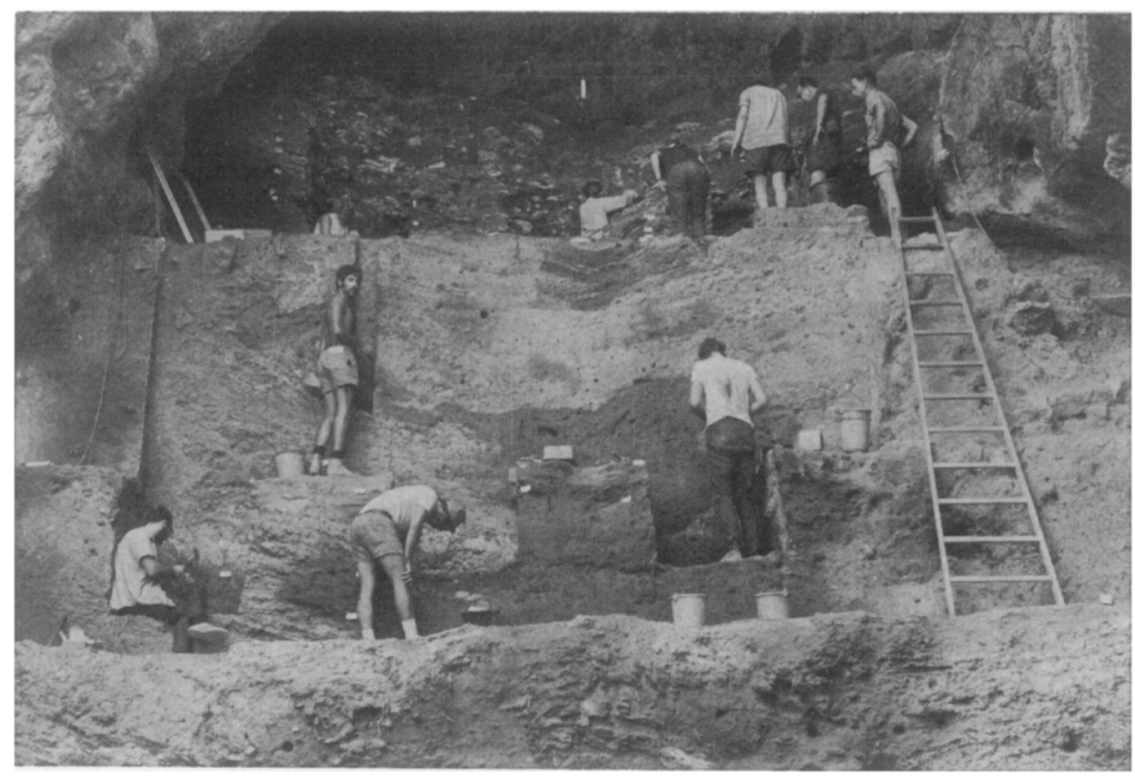

Figure 3. Working face of Tabun excavations as it appeared in 1968. The lowest sediments shown are typical aeolian sands of Tabun E and F; in the middle part of the photograph the loess-like silts of Tabun D are well exposed: behind the topmost figures one can see the red clay and limestone blocks that characterize Tabun B. Compare with Figure 6.

non-deposition and pedogenesis; see column 3, Figures 6 and 7 (Farrand \& Ronen, 1974). The lower of the two persistent palaeosols has yielded numerous mousterian artifacts (Ronen, 1977), while the upper palaeosol has produced epipalaeolithic implements. Moreover, radiocarbon dates from the uppermost kurkar fall in the range from 10,000-7,000 years ago (Farrand \& Ronen, 1974). Thus, we have reasonable confidence in placing the dunes and palaeosols into the Mediterranean marine chronology, especially as it is now understood in the Levant based on the work of Sanlaville (1969, 1973). The $+39 \mathrm{~m}$ beach along the foot of Mount Carmel plus the two major regressional dune series nearer the present coast appear to find their parallels in the three sea level maxima called Enfean I and II and Naamean in Lebanon and marine stages Y1, Y2, and Y3 of Mallorca (Butzer, 1975).

There are, however, differences of opinion concerning the stratigraphic placement of the Israeli coastal aeolianites. Brunnacker (unpublished) suggests a range of 70,000 to 35,000 B.P. for the mousterian palaeosol ("Soil 3" of my Figure 6) and 17,000 to 11.000 
B.P. for the epipalaeolithic palaeosol ("Soil 5" of Figure 6) on the basis of the contained artifacts. I prefer nevertheless a greater age for Soil 3, on the basis of parallels between it and two dated sites in Lebanon. At Ras el-Kelb similar mousterian artifacts are dated "greater than 52,000 years ago" (Garrod \& Henri-Martin, 1961), and at Naâmé mousterian artifacts in a red breccia are sandwiched between shoreline deposits (Fleisch et al., 1971) dated by uranium disequilibrium methods. Unfortunately both the overand underlying beds yielded an age of 90,000 B.P. (Sanlaville, 1971, 1973). While these determinations are not entirely satisfactory, they are consistent with the Ras el-Kelb date and suggestive of a mousterian presence in the Levant during the last interglaciation. Accordingly I have suggested (Column 9, Figure 6) that the two high sea levels at Naâmé be correlated with the 105,000 and 82,000 B.P. sea level peaks recognised elsewhere.

Continuing upwards in the Tabun sequence, we find that the deposits become progressively siltier in the upper part of Tabun E. Tabun D strongly resembles loess, being composed of $55-80 \%$ silt-sized particles. These relations suggest that sea level was quite low at that time so that the local source of aeolian sand in the littoral area was stabilized; thus only long-distance transport of dust, presumably from the Sinai and Egyptian deserts, contributed to the sedimentation in Tabun (Figure 2a). Pollen evidence of Horowitz (in Jelinek et al., 1973) reveals a strong increase in tree vegetation, indicating moist conditions at that time, Moreover, the upper beds in Tabun D have been strongly disturbed by channelling and slumping, this time into a cavity located below the inner chamber of the cave.

A major change then took place in Tabun (Figure 2b). Bed C includes lenses of red clay and head-sized blocks of limestone, neither of which is found in the lower beds (Figure 3 ). Moreover, the heavy mineral suite is dominated by $80-90 \%$ relatively unstable hornblende and epidote, which are of minimal importance $(>10 \%)$ in the lower sequence (Jelinek et al., 1973, p. 159). Furthermore, bones are preserved in Tabun C and B, but not in beds $\mathrm{D}$ to $\mathrm{G}$ where bone material has been dissolved and redeposited as collophane and other secondary phosphate minerals (Goldberg \& Nathan, 1975).

It is difficult to attribute this drastic change from Tabun D to $C$ directly to climate. It is more likely a result of climatic change that set in much earlier, bringing about a gradual enlargement of the inner chamber and finally the opening of the "chimney", which allowed red soil from the overlying plateau to wash rapidly into the cave. The "chimney" opening, now some $5 \mathrm{~m}$ in diameter, drastically changed the microclimate of the cave interior, destroying a habitat for bats, among other things. Without bats and their guano deposits the weathering "climate" within the cave would no longer have so aggressively attacked the accumulating bones and heavy minerals. Thus, I have suggested (in Jelinek et al., 1973) that the change in character of the Tabun sediments must be attributed in the first place to a change in the cave configuration and only indirectly to climatic change. Conditions more moist than today seen in the pollen of bed $\mathrm{D}$ continue through the time of bed C (Jelinek et al., 1973).

In summary, the sedimentary succession in Tabun begins with aeolian sands that can be related to three sea level peaks of the last interglacial period. These sands are followed by siltier deposits, accompanied by an increased arboreal vegetation during a time that must be equivalent to pleniglacial conditions of the first half of the last glaciation. These moister conditions eventually brought about changes in the cave that drastically changed the style of sedimentation.

Absolute dating of the et-Tabun sequence is still far from satisfactory. Several finite radiocarbon ages have been determined for beds $B, C$ and $D$, but some of them are stratigraphically inverted, probably indicating problems of contamination (Jelinek et al., 1973). Even the oldest date, $51,000{ }_{-3000}^{+4800}$ b.p. (GrN-7409) from bed C (Figure 7), 
should be considered a minimum age. It is supported in a general way by a 44,000 B.P. amino-acid determination (Bada \& Helfman, 1976) from a slightly lower level as well as by a 60,000 to 90,000 B.P. thermoluminescence dating (M. L. Aitken, pers. comm.), but neither of these dating methods can be considered definitive at the present time. The lower part of Tabun B is not younger than 39,700 B.P. (GrN-2534), and on the basis of its levalloiso-mousterian industry the uppermost Tabun deposits (now entirely removed) are not younger than c. 35,000 B.P.

\section{The cave of Jebel Qafza, Nazareth, Israel}

The Qafza cave is not far from Tabun (Figure 1), but its setting is distinctly different. It is situated about $220 \mathrm{~m}$ above sea level, in a steep, narrow wadi incised in the Galilean upland, some $35 \mathrm{~km}$ from the present shoreline. Although present winters are somewhat more rigorous than those of the coastal belt where Tabun is located, the overall climate is not strikingly different. Nevertheless, it appears that these differences might have been accentuated during the time of the last glaciation. There is no evidence of frost action in the sediments of Tabun, but the "terrace" deposits of Qafza have some characteristics of freeze-thaw éboulis (or "frost rubble"). On the other hand, the inner chamber of Qafza does not appear to have been affected by frost action.

The cave, not yet completely described in the literature (Vandermeersch, 1966, 1969. 1977), consists of a large, high-vaulted inner chamber, some 21 by $12 \mathrm{~m}$, that connects by the way of a broad "vestibule" just inside the present drip line to a "terrace" in the open air. The vestibule is the area of greatest abundance of mousterian remains, including the important human burials reported by Vandermeersch. The inner chamber is rimmed by several smaller karstic niches or passages, including a second opening to the exterior, and-like Tabun and numerous other Levantine caves-has a "chimney" connecting with the plateau surface above the cave. In this case, the chimney is completely filled with rock rubble that spreads out as a talus fan inside the cave.

The sediments in the inner chamber of Qafza are strongly different from those of the vestibule-terrace area in several ways. The terrace sediments, at least those which remain down to the present day, are uniquely limestone bedrock rubble, more or less angular. not affected by chemical weathering, with only minor amounts of sand-silt-clay matrix. These sediments are cemented into a concrete-like deposit below the present dripline (Figure 4) and outward toward the wadi, but immediately inside the dripline they are loose and very friable. Some of the human burials are thus lying partly in firmly cemented éboulis, and partly in loose sediment. Moreover, the terrace sediments enclose only a mousterian industry, whereas the inner chamber deposits include upper palaeolithic and post-palacolithic industries as well as mousterian. The fine fraction of the terrace éboulis is dominated by its carbonate fraction; some $70-98 \%$ of the fines are soluble in $\mathrm{HCl}$. Among the clay minerals there is some $10 \%$ well-crystallized kaolinite and $80-90^{\circ}$ montmorillonite, exactly as in the enclosing bedrock. With the exception of a few layers there are very few heavy minerals present in the terrace sediments, and there are none al all in the bedrock. Where some heavy minerals are present, their numbers were so low that meaningful statistics could not be drawn from them, except in beds VI to XII, where epidote, hornblende and augite (all easily weathered minerals) strongly dominate $(75-95 \%)$.

The sedimentological characteristics mentioned above indicate that the terrace deposits accumulated rapidly, possibly by freeze-thaw activity at and just outside the cave entrance. Where exposed to rainfall, they were cemented by calcium carbonate not long after they had been deposited. None of them have been affected in any conspicuous ways by postdepositional weathering. Some 24 individual beds have been distinguished (Tillier \& Vandermeersch, 1976), and below those of historic (Byzantine) age, all repre- 
sent a very similar style of deposition and all contain a mousterian industry. There is, nevertheless, an unconformity near the top of the sequence-between beds VII and IX--. which appears to be the same as that between beds 11 and 12 inside the cave (see below).

The situation inside the cave is quite different. The lowest excavated beds, 12 and 13 of Vandermeersch or F to L of Neuville (1954), can be equated with the terrace deposits through their common industry, but they are almost totally lacking a stony fraction larger than $2 \mathrm{~mm}$. The few stones present are highly weathered, porous and rounded. The fine fraction has relatively little material soluble in $\mathrm{HCl}$, but is enriched in phosphate. No bones are preserved. Hcavy mincrals are vcry rare; examination of four samples yielded a total of only 32 grains altogether (M. Ters, pers. comm.). Although one cannot make very firm statements on that basis, 8 of 12 grains in one sample and 14 of 16 grains in another were rutile and zircon, that is, minerals highly resistant to weathering, thus pointing in the direction of a high degree of weathering of these sediments. The clay minerals also, according to $\mathrm{H}$. Paquet (pers. comm.), indicate strong weathering; the clay fraction consists solely of very altered illite.

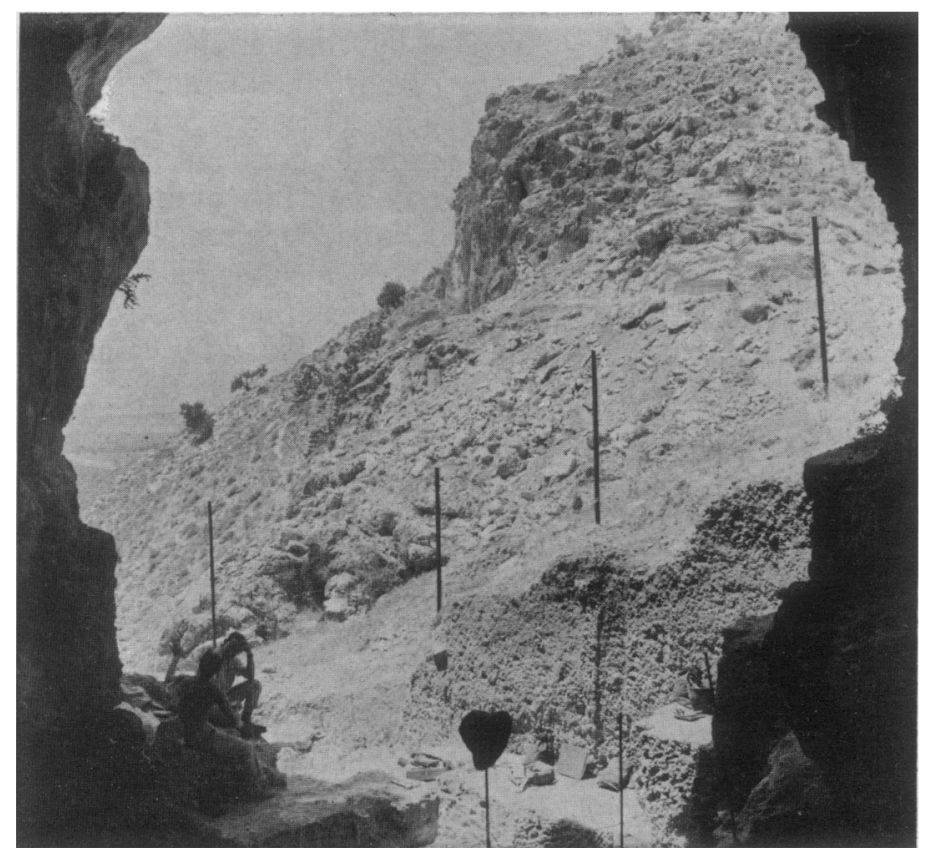

Figure 4. View outwards through the entrance of Qafza Cave, Nazareth, Israel. The firmly cemented, angular limestone rubble (éboulis) is clearly seen in the lower right centre of the photograph.

A clear unconformity (Figure 6) separates beds 12 and 13 from the overlying series; it is marked by differences in colour and degree of weathering as well as an irregular, erosional contact. Moreover, a sudden shift in industries, from middle to upper Palaeolithic, takes place across this unconformity. The amplitude of this hiatus is not yet known. No radiocarbon dates are yet available for this part of the section, and the amino-acid dates of Bada \& Helfman (1976) are not convincing. The latter method yielded ages of 32,000 to 39,000 B.P. for animal bones from bed 9, which is in reasonable agreement with the early upper palaeolithic age assignment of Ronen (1976), but human 
remains from bed XVII on the terrace also fall in the same range, 33,000 B.P., which is out of line with their mousterian industry. Other amino-acid dates on animal bones from the terrace, 49,000 and 57,000 B.P. from beds XXI and XXII, respectively, seem to fit better with our notions of the age of mousterian industries in the Near East, but it is difficult to decide which of these amino-acid ages are acceptable and which must be rejected.

Returning to a description of the sediments of the inner chamber of Qafza, we find that beds 11 to 7 are rather similar and seem to form a single ensemble. They are strong brown in colour, have relatively few rock fragments larger than $2 \mathrm{~mm}$, and the latter are rather rounded, porous and chalky. The acid-soluble component is always less than $35^{\circ}$. and available phosphate is moderately abundant $(100-200 \mathrm{ppm})$. The clays and heavy minerals, on the other hand, show clearly that these beds are not as heavily weathered as beds 12 and 13 . Ten to $20 \%$ each of well-crystallized kaolinite and illite is present along with some $40-45^{\circ}$. montmorillonite and some expandable clays. Heavy minerals are abundant in these layers, predominantly garnet and the non-resistant epidote and hornblende components. Moreover, bones and bone fragments are common. Apparently these sediments have been subject to a modest amount of postdepositional weathering, but that weathering was less intense or lasted a shorter time than in the case of beds 12 and 13. Bouchud (1974) has suggested that the climate was distinctly drier during the time of beds 7 to 9 , based largely on the abundance of Gazella, than it was during mousterian times; this climatic difference may have played a role in determining the different degrees of weathering.

The abundance of heavy minerals and also of quartz grains and certain of the clay minerals is indicative of the introduction of considerable amounts of sediment from outside the cave. These minerals are not found in the local bedrock, or at least not in such proportions. The nonresistant heavy minerals, especially the large grains of augite, suggest a volcanic source rock, according to $\mathrm{M}$. Ters (pers. comm.). There are volcanic rocks enclosed within the local Cretaceous carbonate bedrock within the limits of the city of Nazareth that could have provided such a source. It is not clear, however, how these external sediments entered the cave. The sampled localities are well inside the cave, which seems to rule out effective wind transport. The chimney of the cave is a more likely avenue of access; colluvium from the plateau surface above the cave has completely plugged the chimney at present, and this colluvium emerges within the cave in the form of talus. It seems very likely that much of the sediment of beds 6 to 11 -and probably beds 12 and 13 also-entered the cave by this route. If so, much of the reddish brown colour of beds 6 to 11 might be attributed to reworked soil that originally formed subaerially above and outside the cave, a situation analogous to that of beds $B$ and $C$ at Tabun.

Bed 6 of Qafza looks very much like the colluvium emerging from the chimney shaft. It is much like beds 7 to 11 , although much stonier: moreover, the stones, although rather well rounded, are not chalky and not so porous as those in the underlying beds. Some time gap seems to be implied, therefore, between beds 6 and 7 , but it may not be a great one. Artifacts are quite rare in bed 6 , and no absolute dates are available, so that a more definitive statement cannot be made at present.

Bed 4 is largely composed of hearths, perhaps Neolithic in age. Bed 3 is a stone pavement (dallage) with associated pottery and bronze objects, bringing the succession into historic times. The sediments in these beds are much like those of bed 6 , although the stones tend to be somewhat more angular. They appear to be chimney colluvium also, or else material reworked from the underlying beds.

In summary, the sedimentary sequence (Figure 6) in the cave of Jebel Qafza begins with beds containing a mousterian industry (Figure 7), both inside the cave and on the 
terrace. However, the sediments in those two areas contrast strongly with each other. The terrace consists of very stony, cryoclastic (?) éboulis, still largely fresh and unweathered, although firmly cemented by secondary carbonate. Extraneous material, i.e. not derived from the local bedrock, is rare. Inside the cave the mousterian horizons are made of fine-grained, highly weathered sediment with only occasional stones, no bones, but much secondary phosphate. No post-moustcrian deposits are known from the terrace, but inside the cave the succession continues, after a marked unconformity, through somewhat weathered, mostly fine-grained sediments that must have been introduced via the chimney shaft that debouches into the inner chamber. These beds contain an early upper palaeolithic industry of "non-Aurignacian" affinity (Ronen \& Vandermeersch, 1972). There is no clear evidence of later upper palaeolithic or epipalaeolithic industries, and a question remains about the possibility of another hiatus in the succession between bed 6 (or 5?) and the neolithic-historic industries of beds 4 to 1 . More extensive excavation inside the cave would be necessary to resolve this question.

The absolute chronology of Qafza is still far from satisfactory. In fact, it remains to be demonstrated that the mousterian industries of the inner chamber and of the terrace were contemporaneous. In general, they both appear to correlate with Tabun D and/or C, although a detailed typological analysis is not yet available. Haas (1972) has suggested on the basis of microfauna that the Qafza Mousterian is older than that of Tabun C. On the other hand, the amino-acid dates mentioned above would favour correlation of the Qafza terrace deposits with Tabun C. From a sedimentological point of view one is tempted to suggest a parallel between the strong unconformities of Qafza 11/12 and Tabun C/D. In both cases the underlying beds are heavily weathered, and the unconformity itself is marked by water action. However, in the case of Tabun at least, local changes in the cave configuration may have been more important than regional climatic change. Thus, one must be careful not to jump to conclusions.

\section{Ksar' Aqil rockshelter, Lebanon}

The Ksar 'Aqil rockshelter is located about $10 \mathrm{~km}$ northeast of the city of Beirut (Figure 1) along the north wall of the Wadi Antelias, only about $3 \mathrm{~km}$ from the present coast. The wadi is broad, although its floor is narrow and rocky; it is well supplied with fresh water from several large springs, which are part of a very extensive karstic network. The valley formerly included other important prehistoric sites, the Abri Bergy and the Cave of Antelias, but these have been quarried away in recent years along with much of the limestone ridge that separates the two main branches of the wadi.

The rockshelter itself is situated at the base of a nearly vertical limestone cliff that must have been nearly $50 \mathrm{~m}$ high when sediments hegan to accumulate on this site. Earlier excavations (Ewing, 1947) revealed an impressive succession some $23 \mathrm{~m}$ thick (Figure 6); a general geological description of these sediments has been given by Wright (1962), but the details have never been published. Unfortunately the original excavation was filled in, and only the upper $8 \mathrm{~m}$ (Figure 5) have been excavated so far by Tixier (1974). It will be years before the lower sediments are exposed again, so we have to rely on the original excavators' descriptions.

The lower 6 or $7 \mathrm{~m}$ of the sedimentary fill is composed of alluvial sands and gravels and contains mousterian artifacts. This alluvium reflects the earlier course of the wadi stream against the foot of the high cliff. In other wadis nearer the coast such alluvium interfingers with fossil dunes, which themselves extend below present sea level (Wright, 1962), leading to the conclusion that the period of alluviation can be correlated with a time of low sea level, thus a time of extensive continental glaciation. Wright (1962) related the alluvium to the "Würm" phase, i.e. the last glaciation in our sense. The 
mousterian industry in and just above the gravels, as well as a radiocarbon date of 43,750 b.p. (GrN-2579), confirms this correlation.

Our observations in recent years have revealed another, higher and older, alluvial accumulation in the Wadi Antelias. This deposit lies some $6 \mathrm{~m}$ above the top of the Kar 'Aqil sediment accumulation, but is not found in the rockshelter itself. Thus, it must be older than the cntirc filling in the site, and presumably relates to a period of alluviation during a glacial episode prior to the last glaciation. Following that alluviation the wadi must have incised some 25 or $30 \mathrm{~m}$, at least down to the rock floor of the Ksar 'Aqil shelter, before it accumulated some $15 \mathrm{~m}$ or so of alluvial sediments during the last glaciation.

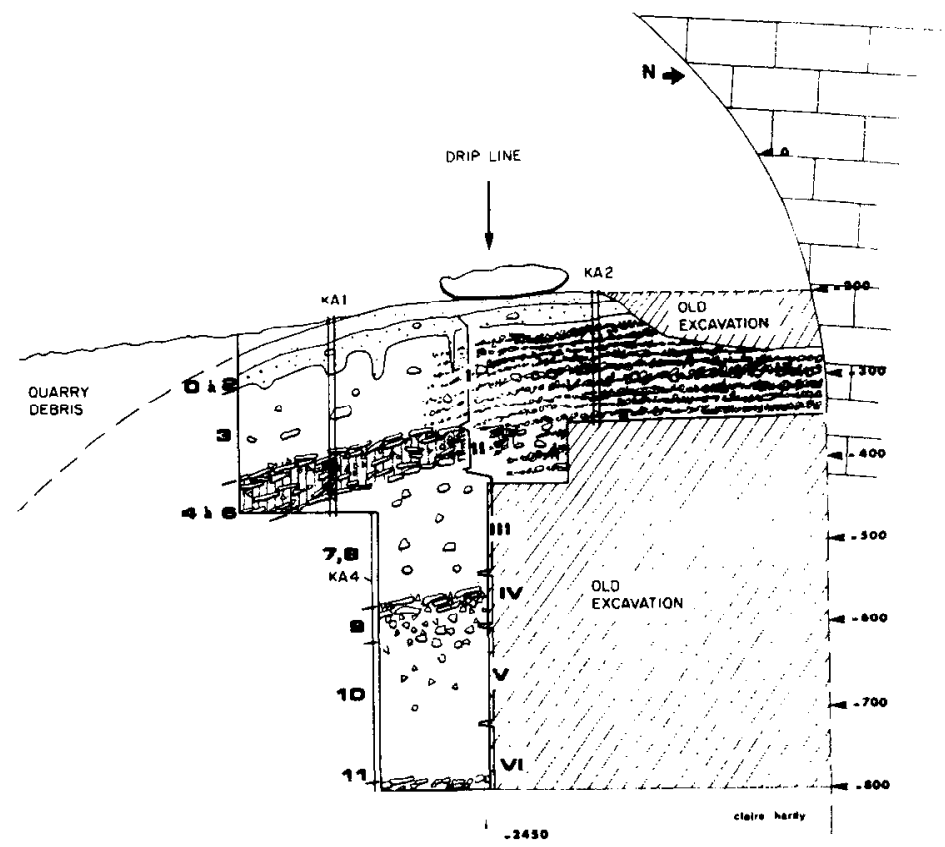

Figure 5. Simplified sagittal section through Ksar 'Aqil rockshelter as exposed in recent excavations (slightly modified from Tixier, 1974). Individual habitation layers are well preserved, encrusted with secondary carbonate inside the drip line, whereas Ewing's "Stony Complex I" (beds 4-6) stands out most clearly outside the drip line. Ewing's "Stony Complex 2 " lies at least $2 \mathrm{~m}$ below this section, whereas the stone-rich layers 9 and 11 shown here were not discussed by Ewing. Approximately 16 more $m$ of sediment remain to be excavated below this section. KA 1, KA 2 and KA 4 are locations of columns of sediment samples being studied by the writer.

Overlying the basal alluvial deposits in Ksar 'Aqil is some $16 \mathrm{~m}$ of "calcareous brown earth" interrupted by several "stony complexes" (Wright, 1962; Ewing, 1947); see Figures 5 and 6 . Three such stony complexes were recognised during the original excavations, and they have been the subjects of considerable speculation concerning their interpretation, most recently by Copeland (1976) and Ronen (1976), both of whom correlate the stony complexes with gaps, unconformities or disturbances in other cave sites throughout the Levant. The stony complexes are beds with an unusual abundance of limestone fragments interlayered with or mixed with red clay. The red clay appears to be reworked red soil (terra rossa) that has washed into the rockshelter from the surrounding 
slopes at a time when spalling of rock from the back wall of the site was particularly frequent. In reality there are more such stony complexes in Ksar 'Aqil than the three mentioned by the original excavators, and they are not all of the same degree of development. In the upper $7 \mathrm{~m}$ recently re-excavated we have recognised not only "Stony Complex l" of Ewing (1947) but also two other, less pronounced red clayey horizons with abundant limestone fragments (beds $9-10 a$ and $10 \mathrm{i}-11$ of Tixier, 1974), and we have not yet reached the level of Ewing's "Stony Complex 2."

The occurrence of relatively fresh, angular limestone fragments (commonly between 5 and $25 \mathrm{~cm}$ maximum diameter in Stony Complex 1) in intimatc association with weathered red clay is genetically incompatible, as Wright (1962) recognised, and argues strongly against pedogenic weathering in situ. As suggested above, it is more logical that this red clay was washed into the shelter, and thus the alternation of red clayey sediments with "brown earth" layers suggests alternating episodes of accelerated slope wash and more stable conditions on the surrounding landscape. The episodes of accelerated slope wash were presumably times in which more intense rain storms, perhaps combined with a reduced vegetation mat, were able to erode the exposed soil more effectively. [See Butzer (1975, p. 32) relative to the interpretation of red colluvial silts in the Mediterranean basin.] Whether the red stony clay layers in Ksar 'Aqil represent more humid or drier climatic intervals is at the present time an open question, but whatever their interpretation might be, the alternation of red clay and brown earth in the rockshelter implies alternation between periods of slope stability and accelerated slope erosion, ultimately linked to changing climatic conditions

On the other hand, the absence of typical freeze-thaw debris in Ksar 'Aqil sediments argues against freezing conditions locally. If so, the angular limestone fragments must have been produced by some other means, perhaps hydration shattering (White, 1976), which would also have been accelerated during times of more intense rain storms, the latter inducing deeper penetration of moisture into the soil and rock surfaces.

Three radiocarbon dates are available for the upper $7 \mathrm{~m}$ of the Ksar 'Aqil sequence: 14,100 b.p. (MC-411) in Stony Complex 1; 28,500 b.p. (GRO-2195) on snails collected between 6 and $7.5 \mathrm{~m}$; and 32,000 b.p. (unpublished) within bed 11 of Tixier (1974). The industries that are found in these layers are Levantine Aurignacian through epipalaeolithic (Tixier, 1974). Thus, we see clear evidence of alternation of effectively wetter and drier climates during the latter half of the time of the last glaciation in this area.

\section{Other Near Eastern sites}

Three other sites where sediments have been studied in detail are included in Figures 1, 2,6 and 7. The first of these is the cave of Sefunim (column 4, Figures 6 and 7), a mediumsized cave also on Mount Carmel in Israel, about halfway between et-Tabun cave and the city of Haifa (Ronen, 1968). Unlike Tabun it does not face the Mediterranean Sea, but is situated a short distance upstream from the mountain front along the wall of a small, steep valley. Sediments were examined from both inside the cave and on the "terrace" at the cave mouth (Ronen \& Farrand, in press). The terrace deposits consist primarily of red clayey, stony colluvium that had been washed from the slopes above the cave. Following the accumulation of beds VII and VI, which enclose a mousterian industry, there was a long period of pedogenesis that resulted in a well-developed, dark reddish brown soil with prominent $\mathrm{CaCO}_{3}$ concretions (Cca horizon). No upper palaeolithic habitation was found on the terrace. The character of the sediments inside the cave is quite different from those on the terrace. They are mainly fine-grained sediments, predominantly silt and clay on a carbonate-free basis. Neither the quartz-rich silt nor its heavy mineral suite could have been derived from the enclosing limestone. They must have come from the nearby coastal plain, either blown directly into the cave or first on to 
the surrounding slopes then washed into the cave. These deposits contain very few rock fragments larger than $2 \mathrm{~mm}$ and there is very little evidence to suggest that freeze-thaw played a role in their origin. Moreover, the lowest sediments-layers 11,12 and 13 with a mousterian industry - are strongly weathered, similar to beds VI and VII of the terrace. On the other hand, the youngest sediments inside the cave, especially beds 5 and 7 . represent quite a different mode of deposition. They consist of loose, open-work rubble (éboulis secs), up to $1 \mathrm{~m}$ thick, that is mostly logically attributed to earthquake-induced breakdown of the cave ceiling. The artifacts in these stony layers are neolithic or younger, i.e. later Holocene in age.

The rockshelter of Yabrud I (column 7, Figures 6 and 7) is located on the eastern slope of the Anti-Lebanon mountains, facing the Syrian Desert (Figure 1). It lies about $1400 \mathrm{~m}$ above sea level in an area that experiences some snow accumulation and freezing temperatures every winter. The rockshelter was most recently excavated in the early 1960s (Solecki \& Solecki, 1966) and the sediments have been analysed by Goldberg (1971) and by Brunnacker (1970). The shelter is filled with $11 \mathrm{~m}$ of sandy, stony éboulis, very coarse (dominantly 16-64 mm) at the base and finer upwards. The lower half of the sequence, up to $5 \mathrm{~m}$ depth, is reddish brown and is interrupted by a $30-\mathrm{cm}$ thick layer of wellsorted. stone-free sand (Flugsand of Rust), apparently representing a short episode of dominantly acolian input. Above $5 \mathrm{~m}$ the colour is pale yellowish brown and the sediments have been more or less cemented with secondary calcium carbonate.

The palaeoenvironmental and chronological interpretations are not readily apparent at Yabrud. The sequence appears to be one of more or less continuous deposition from botiom to top. The coarse sediments at the base ( $-\mathrm{D}$ in Figure 6) presumably resulted from a cold, damp cryoclastic climate, 'glacial' in the hemispheric sense. The overlying sediments (I-C of Figure 6) with the intercalated Flugsand perhaps reflects a climate not unlike that of today, whereas the uppermost $5-\mathrm{m}$ pale-coloured, carbonate-cemented sediment suggests once again a cooler, moister climate. Since no upper palaeolithic industries were found in these deposits the entire section must be older than $c .35,000$ B.P. Moreover, the so-called "pre-Aurignacian" industries found in unit I-B are also found on the Mediterranean coast where they are associated with raised shoreline deposits attributed to the last interglaciation. In view of the chronological uncertainty and the lack of clear environmental indicators, two interpretations of the Yabrud stratigraphy are given in Figures 6 and 7, namely, unit I-D might be attributed to the final phase of the next-to-last glaciation or alternatively to a period of minor climatic deterioration that separated the high sea level peaks of the last interglaciation.

The small cave of Jerf 'Ajla located in the Syrian Desert just $12 \mathrm{~km}$ northwest of the Oasis of Palmyra, or about $150 \mathrm{~km}$ northeast of Yabrud (Figure 1). The most recent excavation and analysis of this site is that of Schroeder (1971), and the sediments were analysed by Goldberg (1971). The sediment accumulation here is only about half as thick $(c .6 \mathrm{~m})$ as at Yabrud, but the presence of a distinct weathered horizon and a finite radiocarbon age determination (column 8, Figures 6 and 7) permit a somewhat more definitive interpretation than was possible for Yabrud. In general, however, the sediments in Jerf 'Ajla are quite similar to the sandy, stony éboulis of Yabrud and presumably represent a mix of cryoclastic debris from the cave walls and aeolian sand and silt blown in from the adjacent desert surface. A dark-coloured weathered horizon cuts across the section at a depth of $2.9 \mathrm{~m}$; relative to the over- and underlying sediments the stones in this layer are more rounded and more porous, and the fine fraction has less $\mathrm{CaCO}_{3}$ and a lower $\mathrm{pH}$. Nevertheless it is not a highly weathered horizon, and presumably not of interglacial rank. Another, even less marked weathered horizon occurs at $4.9 \mathrm{~m}$ depth.

The chronology of Jerf 'Ajla is controlled by a date of $43,000 \pm 2,000$ b.p. on charcoal in unit $\mathrm{D}$, about $70 \mathrm{~cm}$ above the stronger weathered horizon. The top of the section 
contains artifacts of a character transitional between middle palaeolithic and upper palacolithic (Schroeder, 1971), presumably no younger than c. 35,000 B.P., and there is nothing in the nature of the sediments near the base of the section to indicate an "interglacial" environment. Therefore, the entire section at Jerf 'Ajla appears to belong to the first half of the last glaciation, and the weathered horizon would have been formed $c$. 50,000 B.P. (Goldherg, 1971).

\section{Conclusions}

\section{Summary of sedimentological observations}

The nature of the sediments, the unconformities and pedogenetic intervals discussed above are shown schematically in Figure 6 for purposes of correlation and comparison with other chronologies. The same stratigraphic columns are shown again in Figure 7 where the names of the associated prehistoric industries have been added. Two separate figures have been used in order to emphasize the principlc of indcpendence, namely that the artifacts have not been used in establishing the correlations that are shown. Once the correlations have been determined on a geological basis (including the possible use of fossils and radiometric dating) the questions of cultural change in time and space can be approached.

The sequences of sediments, unconformities and soils have been, first of all, placed with respect to those absolute dates that appear to be credible. Clearly there are not enough absolute dates, and there are conflicts between dates determined by different methods. In general, radiocarbon dates are preferred over amino-acid, thermoluminescence and uranium/thorium dates, and there are discrepancies even within the latter groups. The intervals represented by unconformities and by pedogenesis can be only loosely estimated in some cases. All in all, there is ample room for improvement of this correlation chart, a fact that should be kept closely in mind when comparing it to the chart of vegetational history (Figure 8), which for the most part has better radiocarbon control.

Certainly there are many more prehistoric sites in the Near East that should be correlated with those on Figures 6 and 7 to achieve a broadscale man-land reconstruction. Unfortunately detailed sediment analyses are not available for these other sites, and therefore this kind of fine-scale geological correlation is not yet possible. For some important sites, such as es-Skhul on Mount Carmel, this kind of correlation will never be possible because every bit of sediment was removed during earlier excavations.

Figure 6. Correlation chart of upper Quaternary prehistoric sites in the Levant. Basic data are from the following sources:

Column 1. Marine stages follow Bonifay (1975) and Sanlaville (1969); the absolute chronology is taken from dates in the western Mediterranean (Stearns \& Thurber, 1965) that match well with those of Barbados (Mesolella et al., 1969), New Guinea (Bloom et al., 1974) and many other places around the world; dating of the early part of the Weichselian glaciation has recently been refined by Grootes (1978). Amino-acid dates are taken from Bada \& Helfman (1976).

Column 2. Jelinek et al. (1973); Jelinek (1975).

Column 3. Farrand \& Ronen (1974); Ronen (1977).

Column 4. Ronen (1968); Ronen \& Farrand (in press).

Column 5. Vandermeersch $(1966,1969)$; Neuville (1951); Ronen \& Vandermeersch (1972); Ronen (1976).

Column 6. Tixier (1974); Copeland (1976); Wright (1962); Ewing (1947); and unpublished information.

Column 7. Farrand (1970); Goldberg (1971); Soecki \& Solecki (1966).

Column 8. Schroeder (1971); Goldberg (1971).

Column 9. Sanlaville (1969); Fleisch et al. (1971). 

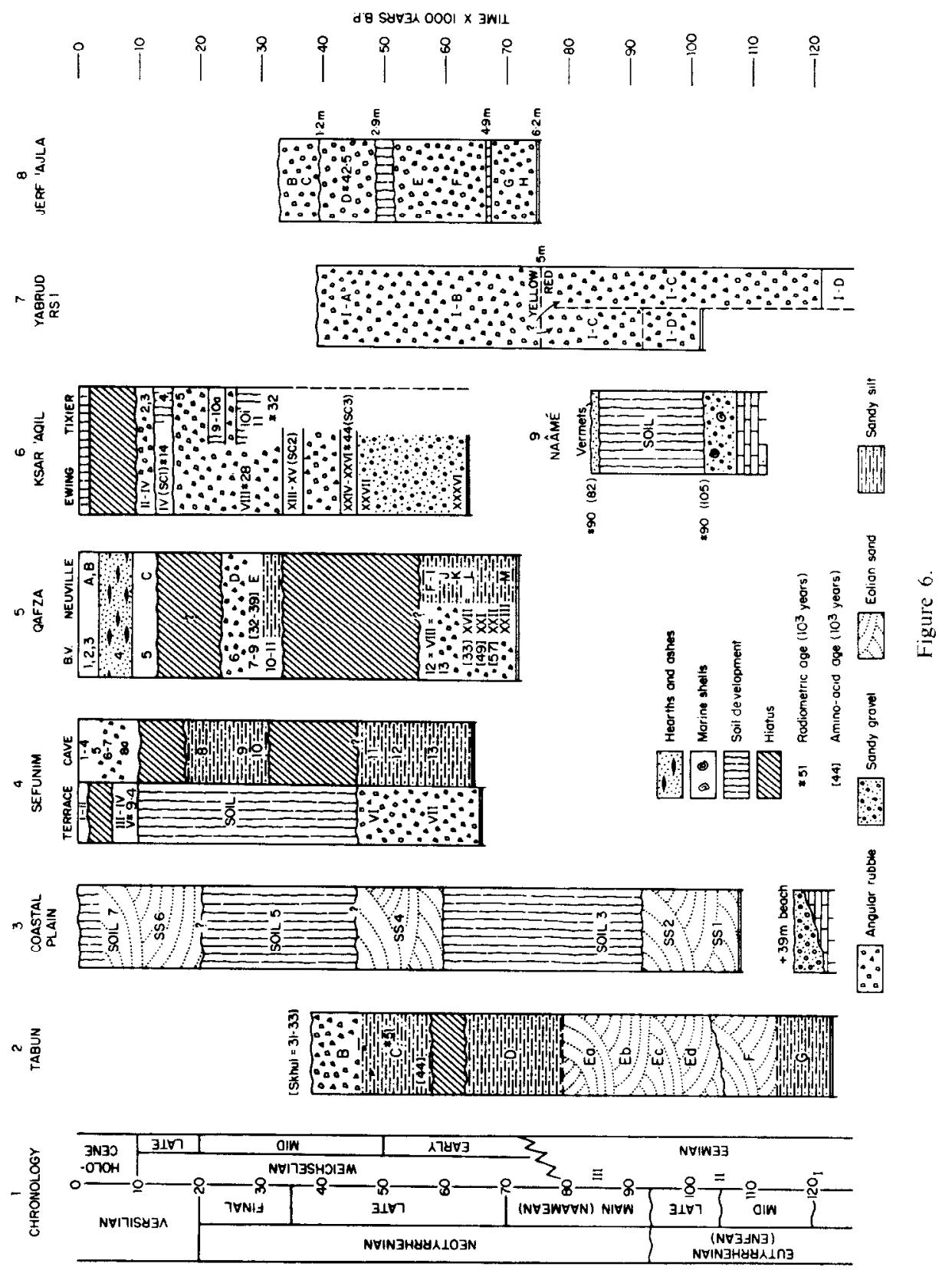


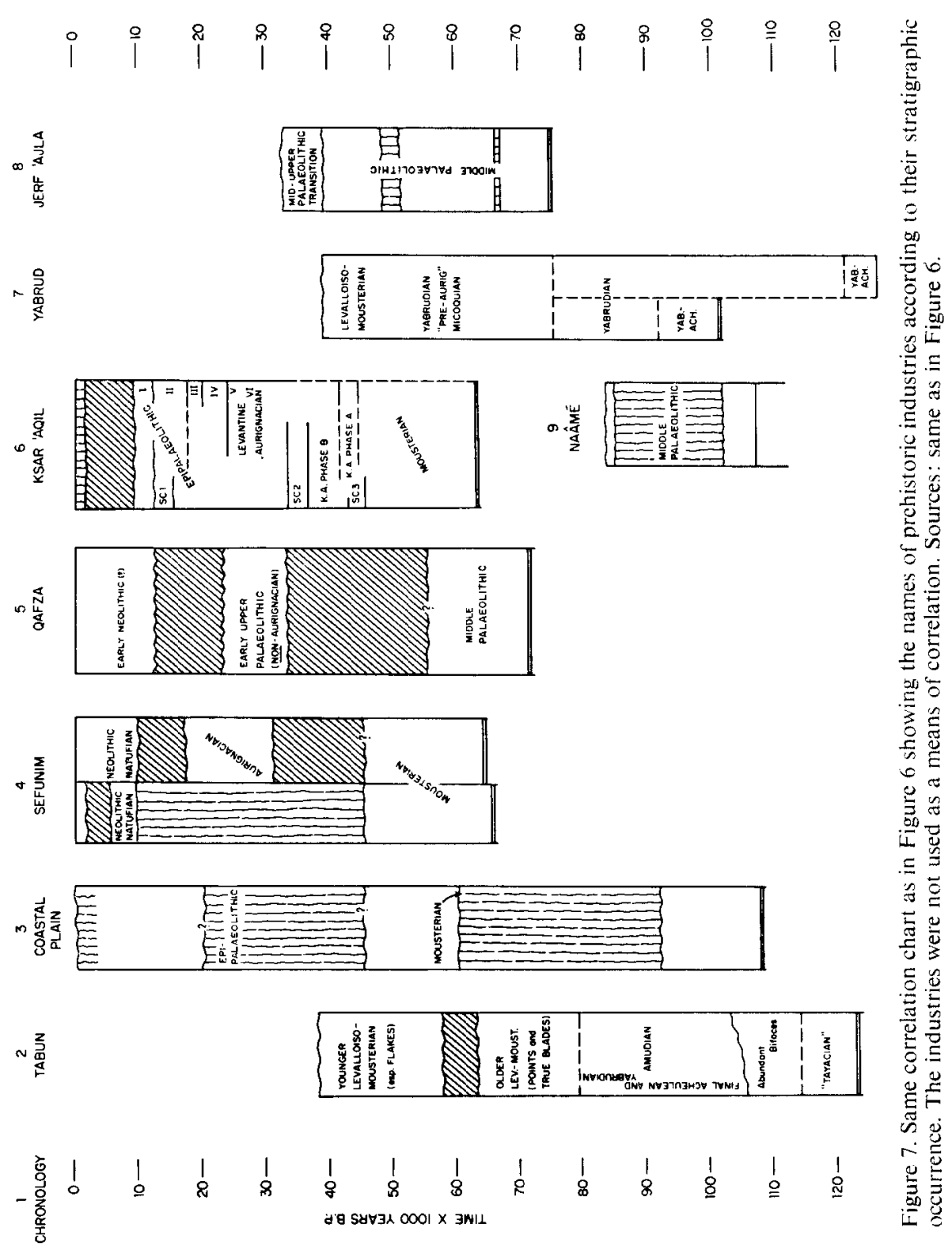




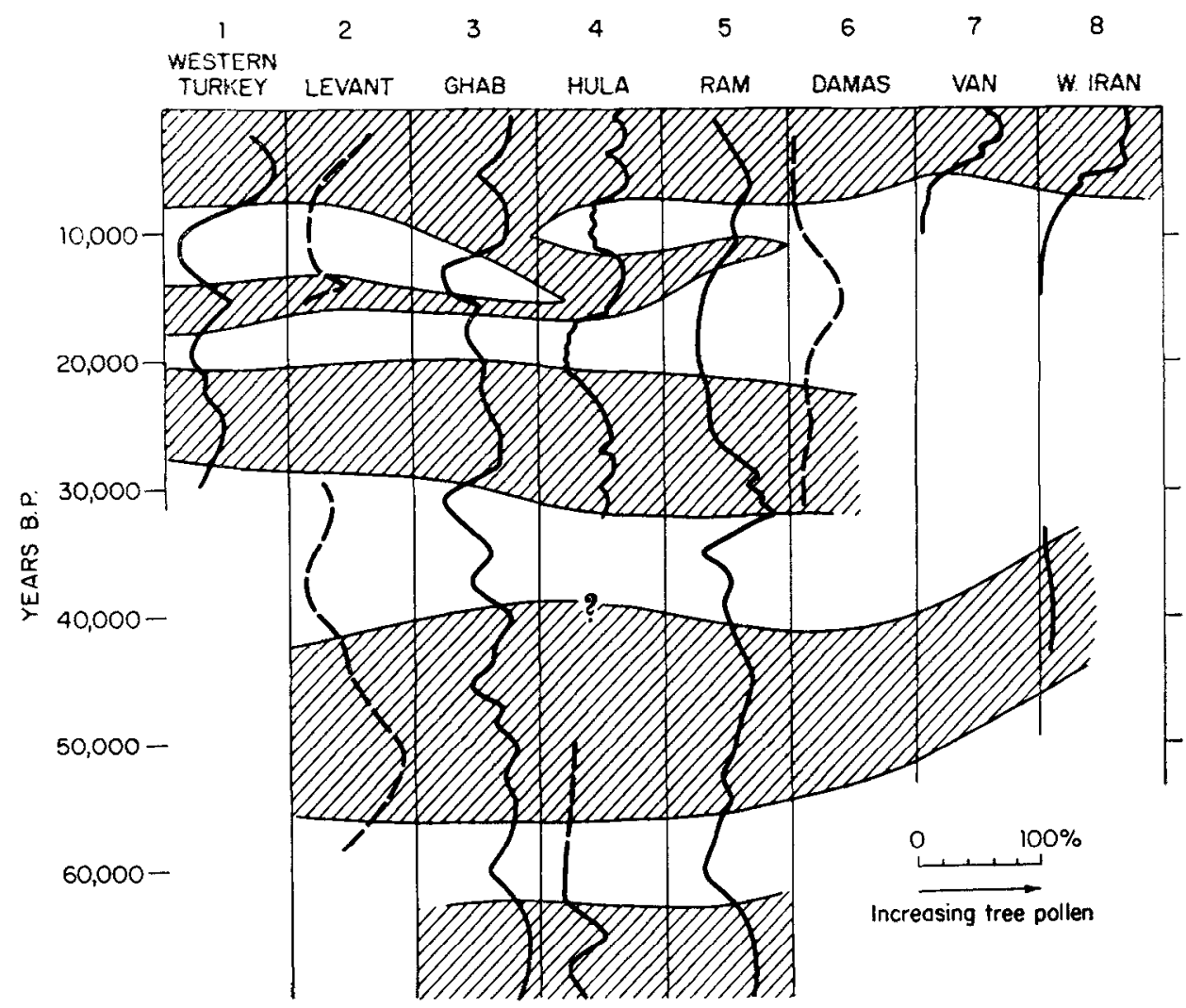

Figure 8. Simplified vegetational history of the Near and Middle East based on curves of percent tree pollen in the total pollen spectra, as given by the original workers. Episodes of relatively high quantities of tree pollen have been correlated from site-to-site as shown by diagonally ruled areas on the diagram. These episodes can be interpreted as periods of increased effective precipitation, and some were apparently somewhat cooler than today especially those episodes between $c 56,000$ and 44,000 B.P. and tetween $<$. 32,000 and 21,000 B.P., based on increased percentages of upland conifers among the tree pollen. Radiocarbon age control is relatively good for all these sites except columns 5 and 6 . The dashed curves of columns 2 and 6 are based on composites from several difierent sites rather than a single, vertical core.

Sources:

Column 1. Lake Söğüt (van Zeist et al., 1975).

Column 2. Prehistoric sites in Syria and Lebanon (Leroi-Gourhan, 1973).

Column 3. Ghab depression, northern Syria (Niklewski \& varl Zeist, 1970).

Colum 4. Lake Hula, northern Israel, 30,000 B.P. to present (M. Tsukada. unpublished), 30,000 to more than 60,000 B.P. (Horowitz, 1971).

Column 5. Birket (lake) Ran., Golan Heights (Weinstein, 1976).

Column 6. Damascus basin (Arlette Leroi-Gourhan, pers. comm: and in Kaiser et al., 1973).

Column 7. Lake Van, eastern Turkey (van Zeist \& Woldring, 1978).

Column 8. Lake Zeribar, western Iran (van Zeist \& Boitema, 1977 ). 
For comparison of the conclusions reached herein, one can turn to more ambitious correlation charts drawn by Besançon, Copeland \& Hours (1972, 1977) for Palestine, Lebanon and Syria. Essentially all known sites are included, as well as environmental information drawn from pollen and regional geomorphology, much of which cannot be directly related to site stratigraphy. However, no site sedimentology was incorporated because it was largely unknown at the time of publication of those articles. Concerning the sites discussed in the present article, the correlation charts of Besançon and colleagues do not include (1) the post-middle palaeolithic horizons of Qafza, (2) the currently understood stratigraphy of Iraq cl-Barud [=Scfunim (Ronen, 1968)], (3) the current stratigraphy and radiocarbon dates resulting from the recent excavations at Ksar 'Aqil (Tixier, 1974), or (4) the current interpretation of et-Tabun (Jelinek et al., 1973). Nevertheless, their placement of strata of these sites corresponds quite reasonably well in a general way with the absolute ages given in this article (Figure 6). On the other hand, a bed-by-bed comparison is not possible because of the more generalized nature of their charts. It is hoped that the value of more detailed correlation by means of sediment analysis will become evident by a comparison of Figure 6 and the charts of Besançon et al., $(1972,1977)$. However, much sedimentological work remains to be done before such detailed correlations can be made of the majority of Near Eastern sites.

\section{Comparison of site sediment history with other records}

For purposes of comparison of the palaeoenvironmental record from prehistoric sites with other independent evidence, one can turn to the records from palynology, palaeolimnology (especially "pluvial lakes"), and deep-sea cores. All these records are spotty and open to various interpretations, but general patterns are emerging and appear to be reasonably consistent with more substantial records from other areas.

The best dated and most detailed record in the Near East is that of palynology. However, van Zeist has written that one must be extremely cautious in interpreting the pollen record from such a varied and vast region as the Near East because that record is so sparse and fragmentary. He warns "not to draw far-reaching conclusions from too scanty evidence" (van Zeist \& Woldring, 1978, p. 275). Nevertheless, there are strongly suggestive similarities among the pollen diagrams from western Turkey to western Iran. Unfortunately only three continuous records extend back in time beyond c. 30,000 B.P., but they reinforce each other with a consistent pattern (Figure 8).

Limiting oneself to the major, prominent fluctuations of arboreal pollen, one can sort out several episodes during the last 70,000 years or so when the percentage of tree pollen was relatively high across the entire Near Eastern sector. As represented in Figure 8 these episodes may not have been exactly synchronous, and there appear to have been distinct geographical ("facies") differences across the region at times. Moreover, a number of uncertainties are involved in this interpretation: uncertainties in translating the pollen diagrams into former vegetation types and uncertainties in the chronologies of each pollen diagram. Figure 8 , therefore, represents my own, conservative interpretation of vegetation history. Nevertheless, four or five distinct periods of high arboreal pollen stand out from intervening intervals in which arboreal pollen was reduced to half or less than half the preceding and following values. (More detailed interpretation of the pollen diagrams would be beyond the scope of this article; in any case this information is presented simply as an indication that independent evidence of climatic fluctuations is available, even though correlation is not yet certain between the different kinds of records.)

It is always difficult to sort out the relative roles of temperature change and precipitation change in reading climatic fluctuations from the pollen record. (The same is true for shifts in snow lines and for the varying levels of pluvial lakes.) In the case of the Near 
Eastern pollen record not all the intervals of high arboreal pollen were of the same character. Some intervals were marked by relative increases in upland conifer pollen, implying cooler as well as relatively moister conditions. However, the latest interpretation of Mediterranean sea-surface temperatures (Thiede, 1978; see also Thunell, 1975) reveals that the water 18,000 years ago was only $1-3{ }^{\circ} \mathrm{C}$ cooler than now. Therefore, it is unlikely that air temperatures in the Levant were markedly cooler than at present. The situation may have been much different in Iran which would have been under the influence of cold, dry air masses from central Asia at that time. These differences in temperature apparently explain the absence of trees in western Iran and their abundance along coastal Levant in the period between 35,000 and 15,000 years ago (van Zeist \& Bottema, 1977).

Finally, then, comparisons can be made of the relatively humid episodes interpreted from the pollen record and the environmental interpretation of prehistoric site sediments (Table 1). "Humid Interval" should better be read as "Interval of Abundant Arboreal Pollen" and in any case it must not be automatically assumed that there was an absolute increase in atmospheric precipitation in each of the intervals listed in Table 1. In general, $\mathrm{c}$ ne finds that the humid intervals correspond to times of alluviation, mass movement (colluviation), precipitation of secondary carbonate, weathering and even pedogenesis, that is, phenomena involving relatively abundant supplies of water. Therefore, as a first approximation, the sedimentary record and the vegetational history seem to reinforce each other.

Table 1. Comparison of the Near Eastern pollen record with cave and rockshelter sediments.

\footnotetext{
Humid Interval 5: c. 8000 B.P. to present.

Holocene soil development: Soil 7 on Coastal Plain, and surface soils at Ksar 'Aqil and on "terrace" of Sefunim.

Humid Interval 4: c. 17,000 to c. 13,000 B.P.

Formation of Stony Complex 1 (SC 1) at Ksar Aqil; elsewhere continuation of pedogenesis or non-deposition; no interruption of dune accumulation (SS 6) on Coastal Plain.

Humid Interval 3: c. 32,000 to 21,000 B.P.

Culmination of pedogenesis of Soil 5 on Coastal Plain; deposition of Sefunim 8-9-10 and Qafza $6-11$ by combination of wind and mass movement; deposition of rubefied layers $10 \mathrm{i}-11$ and $9-10 \mathrm{a}$ at Ksar 'Aqil.

Humid Interval 2: c. 56,000 to 42,000 B.P.

Hiatuses following periods of heavy weathering at Tabun (C/D) and Qafza (11/12); roof and chimney collapse at Tabun; major colluviation of "terrace" deposits and weathering of layers 11-13 inside Sefunim; conclusion of alluviation at Ksar 'Aqil: major weathered horizon at Jerf 'Ajla; cementation of uppermost sediments at Yabrud Rockshelter 1.

Humid Interval I: early "Iast glaciation" to c. 62,000 B.P.

Loess deposition in Tabun with high arboreal pollen $\left(64^{\circ}\right)$; pedogenesis of buried Hamra (Soil 3 ) on Coastal Plain; accumulation of angular rock debris (freeze-thaw?, hydration?) on "terrace" at Qafza; minor weathered horizon $(-4.9 \mathrm{~m})$ at Jerf 'Ajla.
}

\section{Acknowledgements}

I have enjoyed the enthusiastic support of my colleagues who have been excavating the sites discussed above: Arthur Jelinek, Jacques Tixier, Bernard Vandermeersch and Avraham Ronen. Moreover, I am deeply grateful to Mireille Ters for heavy mineral analysis and to Hélène Paquet for clay mineral identification of the Qafza sediments. Various parts of this work has been supported by funds from the U.S. National Science Foundation (to A. J. Jelinek), the Wenner-Gren Foundation for Anthropological Research, and the French Centre National de Recherche Scientifique (RCP 50), as well as the Scott Turner Endowment of The University of Michigan. 


\section{References}

American Commission on Stratigraphic Nomenclature (1970). Code of Stratigraphic Nomenclature (with amendments). Tulsa: American Association of Petroleum Geologists.

Bada, J. \& Helfman, P. (1976). Application of amino-acid racemization in paleoanthropology and archaeology. Union Internationale des Sciences Préhistoriques et Protohistoriques, IXe Congrès, Nice, Colloque I, 39-62.

Bloom, A. L., Broecker, W. S., Chappell, J., Matthews, R. \& Mesolella, K. (1974). Quaternary sea level fluctuations on a tectonic coast: new 230-Th/234-U dates from the Huon Peninsula, New Guinea. Quaternary Research 4, 185-205.

Bonifay, E. (1975). "L'Ere quaternaire": définition, limites et subdivisions sur la base de la chronologie méditerranéené. Bulletin de la Société Géologique de France, 17, 380-393.

Bouchud, J. (1974). Etude préliminaire de la fauna provenant de la grotte du Djebel Qafzeh près de Nazareth (Israël). Paleorient 2, 87-102.

Brunnacker, K. (1970). Die Sedimente des Schutzdaches I von Jabrud (Syrien). Frühe Menschheit und Umwelt. Fundamenta A2, 189-198.

Brunnacker, K. (1975). The mid-Pleistocene of the Rhine basin. In (K. W. Butzer \& G. L. Isaac, Eds) After the Australopithecines. The Hague: Mouton, pp. 189-224.

Brunnacker, K. \& Ronen, A. (1977). The late glacial in the coastal plain of Israel: Abstracts, Xe International Quaternary Congress Birmingham: England, p. 60.

Butzer, K. W. (1975). Pleistocene littoral-sedimentary cycles of the Mediterranean: a Mallorquin view. In (K. W. Butzer \& G. L. Isaac, Eds) After the Australopithecines. The Hague: Mouton, pp. 25-71.

Copeland, L. (1976). Terminological correlations in the early upper Paleolithic of Lebanon and Palestine. Union Internationale des Sciences Préhistoriques et Protohistoriques, IXe Congres, Nice, Colloque III, Terminology of Prehistory of the Near East, 34-38.

Ewing, J. F. (1947). Preliminary note on the excavations at the Paleolithic site of Ksar 'Akil, Republic of Lebanon. Antiquity 21, 186-196.

Farrand, W. R. (1970). Geology, climate and chronology of Yabrud rockshelter I. Fundamenta: Monographien zur Urgeschichte Reihe A, Band 2, Teil 1, 212-223.

Farrand, W. R. (1972). Geological correlation of prehistoric sites in the Levant. UNESCO. The Origin of Homo sapiens (Energy and Conservation 3), 227-235.

Farrand, W. R. (1975). Sediment analysis of a prehistoric rockshelter: the Abri Pataud. Quaternary Research 5, 1-26.

Farrand, W. R. \& Ronen, A. (1974). Observations on the kurkar-hamra succession on the Carmel coastal plain. Tel Aviv 1, 45-54.

Fleisch, H., Comati, J., Reynard, P. \& Elouard, P. (1971). Gisements à Strombus bubonius Lmk. (Tyrrhénien) à Naâmé (Liban). Quaternaria 15, 217-238.

Garrod, D. \& Bate, D. (1937). The Stone Age of Mount Carmel. London: Oxford, vol. 1.

Garrod, D. \& Henri-Martin, G. (1961). Rapport préliminaire sur la fouille d'une grotte au Ras el-Kelb. Bulletin du Musée de Beyrouth, 16, 61-67.

Goldberg, P. (1971). Analyses of sediments of Jerf 'Ajla and Yabrud rockshelters, Syria. Union Internationale pour l'Etude du Quaternaire, VIIIe Congrès INQUA, Paris. Études sur le Quaternaire danx le Monde, 747-754.

Goldberg, P. (1973). Sedimentology, stratigraphy and paleoclimatology of et-Tabun Cave, Mount Carmel, Israel. Ph.D. dissertation, University of Michigan, Ann Arbor.

Goldberg, P. \& Nathan, Y. (1975). The phosphate mineralogy of et-Tabun cave, Mount Carmel, Israel. Mineralogical Magazine 40, 253-258.

Grootes, P. M. (1978). Carbon-14 time scale extended: comparison of chronologies. Science 200, $11-15$.

Haas, G. (1972). The microfauna of the Djebel Qafzeh cave. Palaeovertebrata 5, 261-270.

Horowitz, A. (1971). Climate and vegetational developments in northeastern Israel during upper Pleistocene-Holocene times. Pollen et Spores 13, 255-278.

Jelinek, A. J. (1975). A preliminary report on some lower and middle Paleolithic industries from the Tabun cave, Mount Carmel (Israel). In ( $\Gamma$. Wendorf \& A. Marks, Eds) Problems in Prehistory: North Africa and the Near East. Dallas, pp. 297-315. 
Jelinek, A. J. (1977). A preliminary study of flakes from the Tabun Cave, Mount Carmel. In (B. Arensburg \& O. Bar-Yosef, Eds) Moshe Stekelis Memorial Volume, Eretz Israel 13, $86-96$.

Jelinek, A. J., Farrand, W. R., Haas, G., Horowitz, A. \& Goldberg, P. (1973). New excavations at the Tabun Cave, Mount Carmel, Israel, 1976-1072: a preliminary report. Paleorient 1, 151-183.

Kaiser, K., Kempf, E. K., Leroi-Gourhan, Arl. \& Schütt, H. (1973). Quartärstratigraphische Untersuchungen aus dem Damaskus-Becken und seiner Umgebung. Zeitschrift für Geomorphologie, N.F. 17, 263-353.

Kukla, G. J. (1977). Pleistocene land-sea correlations, I. Europe. Earth-Science Reviews 13, 307-374.

Leroi-Gourhan, A. (1973). Les possibilités de l'analyse pollinique en Syrie et au Liban. Paleorient 1, 39-47.

Mesolella, K., Matthews, R., Broecker, W. \& Thurber, D. (1969). The astronomical theory of climatic change: Barbados data. Journal of Geology 77, 250-274.

Michelson, H. (1968). The geology of the Carmel coast (in Hebrew). M.Sc. thesis, Hebrew University, Jerusalem.

Neuville, R. (1954). Le Paléolithique et le Mésolithique du Désert de Judée. Institut de Paléontologie Humaine, Mémoire 24.

Niklewski, J. \& van Zeist, W. (1970). A late Quaternary pollen diagram from northwestern Syria. Acta Botanica Neerlandica 19, 737-754.

Richmond, G. M. (1970). Comparison of the Quaternary stratigraphy of the Alps and Rocky Mountains. Quaternary Research 1, 3-28.

Ronen, A. (1968). Excavations at the cave of Sefunim (Iraq el-Barud), Mount Carmel-preliminary report. Quartaer 19, 275-288.

Ronen, A. (1976). The upper Paleolithic in northern Israel: Mt. Carmel and Galilee. Union Internationale des Sciences Préhistoriques et Protohistoriques, IXe Congrès, Nice, Colloque III, Terminology' of Prehistory of the Near East, 153-186.

Ronen. A. (1977). Mousterian sites in red loam in the coastal plain of Mount Carmel. In (B. Arensburg \& O. Bar-Yosef, Eds) Moshe Stekelis Memorial Volume, Eretz Israel 13, 183-190.

Ronen, A. \& Farrand, W. R. (in press). Excavations and Geology of Sefunim Cave, Mount Carmel, Israel.

Ronen, A. \& Vandermeersch, B. (1972). The upper Paleolithic sequence in the cave of Qafza (Israel). Quaternaria 16, 189-202.

Sanlaville. P. (1969). Les bas niveaux marins pléistocènes du Liban. Méditerranée 3, 257-292.

Sanlaville, P. (1973). Etude géomorphologie de la région littorale du Liban. Thèse d'Etat, Brest, 3 vols., $792 \mathrm{pp}$.

Schroeder, H. B. (1971). The Paleolithic industries from the Syrian Desert cave of Jerf 'Ajla. Union Internationale pour l'Etude de Quaternaire, VIIIe Congres INQUA, Paris. Études sur le Quaternaire dans le Monde, 1017-1024.

Solecki, R. \& Solecki, R. (1966). New data from Yabrud, Syria, preliminary report of the Columbia University archaeological investigations. Annales Archéologiques Arabes Syriennes $16,121-154$.

Stearns, C. E. \& Thurber, D. L. (1965). Th 230/U 234 dates of the late Pleistocene marine fossils from Mediterranean and Moroccan littorals. Quaternaria 7, 29-42.

Thiede, J. (1978). A glacial Mediterranean. Nature, London 276, 680-683.

Thunell, R. C. (1979). Eastern Mediterranean Sea during the last glacial maximum; an 18,000-years B.P. reconstruction. Quaternary Research 11, 353-372.

Tillier, A. M. \& Vandermeersch, B. (1976). Les enfants moustériens de Qafzeh (Israël). Compte rendus de l'Académie des sciences, Paris 282, 1097-1100.

Tixier, J. (1974). Fouille à Ksar 'Aqil, Liban (1969-1974). Paleorient 2, 183-185.

Vandermeersch, B. (1966). Nouvelles découvertes de restes humains dans les couches levalloiso-moustériennes de gisement de Qafzeh (Israël). Compte rendus de l"Académie des Sciences, Paris 262, 1434-1437. 
Vandermeersch, B. (1969). Les nouveaux squelettes moustériens découverts à Qafzeh (Israël) et leur signification. Compte rendus de l'Académie des Sciences, Paris 268, 2562-2565.

Vandermeersch, B. (1977). Les hommes fossiles de Qafzeh (Israël) 2 vols. Thèse de Doctorat d'Etat ès-Sciences Naturelles, Université Pierre et Marie Curie (Paris 6).

Weinstein, M. (1976). The late Quaternary vegetation of the northern Golan. Pollen et Spores 18, 553-562.

White, S. E. (1976). Is frost action really only hydration shattering? A review. Arctic and Alpine Research 8, 1-6.

Wright, H. E., Jr. (1962). Late Pleistocene geology of coastal Lebanon. Quaternaria 6, 525-539.

Zeist, W. van \& Bottema, S. (1977). Palynological investigations in western Iran. Palaeohistoria 19, 19-85.

Zeist, W. van \& Woldring, H. (1978). A postglacial pollen diagram from Lake Van in east Anatolia. Review of Palaeobotany and Palynology 26, 249-276.

Zeist, W. van, Woldring, H. \& Stapert, D. (1975). Late Quaternary vegetation and climate of southwestern Turkey. Palaeohistoria 17, 44-143. 